\title{
PENINGKATAN DAYA SAING USAHA MIKRO PEMPEK IKAN DAN NABATI SAYURAN TROPIS DI KOTA MALANG
}

\author{
Yuni Agung Nugroho \\ Untung Sugiarti \\ Dosen Program Studi Agroteknologi Fakultas Pertanian Universitas Widyagama Malang
}

\begin{abstract}
ABSTRAK
Kegiatan Pengembangan Ilmu Pengatahuan bagi masyarakat (IbM) didesain untuk mengatasi permasalahan yang dihadapi perusahaan mitra. Pelaksanaan IbM ini akan dilakukan dengan metode sebagai berikut a) Alih teknologi mekanisasi pada produksi pempek, b) Pendampingan Penerapan Standar Sanitasi dan Hygiene Pada Produksi Pempek, c) Pelatihan manajemen, manajemen keuangan produksi dan manajemen pemasaran, d) Monitoring dan Evaluasi.

Hasil kegiatan IbM yang sudah terlaksana adalah bantuan mesin pengaduk adonan pempek diperuntukkan bagi Mitra 2, sedangkan untuk Mitra 1 berupa frezzer polytron dan vacum sealer. Namun mesin pengaduk pempek dapat digunakan, setelah daya listrik pada mitra 2 ditambah dayanya menjadi 1300 watt. Mitra 1 (Pempek Maliana) lebih terbuka dan kreatif dalam mengembangkan produk pempek, sedangkan mitra 2 (Pempek Sulfat 28) masih menganut pempek yang sudah ada di Malang yaitu dengan penampilan yang sama dan keras. Pendampingan dan penyuluhan untuk membuka wawasan dan menambah ketrampilan sudah dilakukan namun pada Mitra 2 masih belum mampu mengadopsinya. Mitra 1 sudah lebih maju dalam hal inovasi dan kreatifitas dalam produk dan pemasaran.

Kata kunci : daya saing, usaha mikro, pempek, sayuran tropis
\end{abstract}

\begin{abstract}
Community Development Activities (IbM) is designed to address the problems faced by partner companies. The implementation of IbM will be carried out by the following methods: a) Transfer of Application of Sanitation and Hygiene Standard to Pempek Production, c) Management training, financial management of production and marketing management, d) Monitoring and Evaluation.

The results of IbM activities that have been done is the aid of mixing machine pempek dough dedicated to Partners 2, while for Part 1 in the form of fretrer polytron and vacum sealer. However, the pempping stirrer can be used, after the electric power of partner 2 plus the power to 1300 watts. Mitra 1 (Pempek Maliana) is more open and creative in developing pempek products, while partner 2 (Pempek Sulfat 28) still adheres to pempek that already exist in Malang with the same appearance and hard. Assistance and counseling to open insight and add skills have been done but at Partner 2 is still not able to adopt it. Partner 1 is already more advanced in terms of innovation and creativity in products and marketing. Keywords: competitiveness, micro business, pempek, tropical vegetables
\end{abstract}

\section{PENDAHULUAN}

Pempek adalah kuliner khas Palembang yang tidak hanya ada di kota asalnya, tetapi juga dikenal dan digemari hampir di seluruh Indonesia. Pempek-pempek di daerah lain umumnya dimakan sebagai kudapan atau makanan selingan. Di Kota Malang, tepatnya di Kelurahan Mangliawan dan Purwantoro, merupakan salah satu daerah pembuat pempek yang belum optimal, padahal berpotensi. Keberadaan industri rumahan pempek perlu dikembangkan karena merupakan mata pencaharian utama bagi keluarga, kondisi ke dua ( 2) mitra (Pempek Maliana dan pempek Sulfat 28) keberadaannya sangat potensi sekali, namun dalam pengusahaannya belum optimal hal ini dikarenakan kondisi lemah dari sisi permodalan, pemasaran dan teknologi. Padahal apabila dikelola dengan melaksanakan fungsi pemasaran akan meningkatkan produksi yang pada akhirnya akan meningkatkan pendapatan produsen. Kondisi pengelolaan masih belum maksimal dalam memanfaat ilmu pengetahuan dan teknologi untuk meningkatkan produksi. Usaha pempek dari kedua mitra menunjukkan bahwa didapat marjin sebesar $60 \%$, hal ini akan mengalami peningkatan keuntungan apabila dikelola secara maksimal dengan memperhatikan orientasi pasar dan peningkatan manajemen serta alat teknologi yang lebih efektif efisien.

Bisnis pempek dengan menggunakan bahan-bahan yang sederhana, dan mudah kita diversifikasi dengan bahan nabati, maka apabila ada yang tidak suka ikan laut dapat menggunakan sayur atau buah yang mudah didapat dan cara pembuatannya juga sederhana, harganya juga relatif murah dan mudah didapatkan. 
Pempek dengan sayuran tropis ini bisa menjadi jajanan khas di Malang, karena pempek ikan yang dimodifikasi dengan rasa sayur bisa menambah nilai gizi dan sehat.

IRT Pempek Maliana dalam memasarkan produknya dengan cara berjualan di rumah dan lewat sosial media, sehingga jangkauan penjualannya lebih luas. Pada hari libur produk pempek Maliana sudah habis pada saat siang hari sudah habis, namun apabila hari biasa pemasaran mengandalkan lewat media sosial. Produk pempek oleh IRT Pempek SULFAT 28 yang diusahakan Ibu Ari Wahyuningtyas Putri dalam hal pemasaran dengan cara berjualan pada lapak milik sendiri, sehingga jangkauan pasar tergantung pada masyarakat sekitarnya dan konsumen yang lewat dekat lapaknya.

\section{PERMASALAHAN}

Pada dasarnya permasalahan yang dihadapai UKM pempek beragam dan saling terkait antara permasalahan yang ada. Untuk mempermudah menangani permasalahan yang ada, maka permasalahan UKM Pempek di Kota Malang dikelompokkan menjadi dua aspek utama yaitu permasalahan produksi dan permasalahan manajemen.

a) Permasalahan Produksi

Walaupun dari hasil analisis situasi pada UKM Pempek mempunyai kondisi yang tidak sama selalu sama, namun setelah dikaji secara mendalam maka secara garis besar permasalahannya yang terjadi hampir sama. Permasalahan produksi teridiri dari:

1) Masalah proses produksi pempek yang terbatas kuantitas produksinya dan membutukan waktu lama. Hal ini disebabkan oleh keterbatasan inovasi peralatan utamanya pada peralatan mixer atau pengaduk adonan pempek untuk skala lebih besar. Dengan keterbatasan peralatan maka kualitas maupun produktifitas pempek masih rendah dan belum mampu bersaing.

2) Masalah penyimpanan bahan untuk adonan yang berasal dari ikan segar dan empek-empek yang sudah jadi, sebatas menggunakan kulkas. Kulkas sebagai penyimpanan bahan ikan segar dan hasil pempek yang sudah jadi sangat terbatas karena suhu simpannya masih diatas suhu beku, sehingga tidak mampu menyimpan untuk waktu yang lama. Hal ini disebabkan oleh faktor keterbatasan peralatan penyimpanan dingin yang hanya menggunakan kulkas.

b) Permasalahan Manajemen
Permasalahan manajemen untuk kedua mitra adalah:

1) Masih menggunakan sistem manajemen konvensional terutama pada pemasaran produk. Sebatas menjual dari kios tempat penjualan. Informasi produk hanya sebatas bisa diketahui dengan mendapat informasi dari mulut ke mulut, dari tetangga ke tetangga. Cara ini sangat tidak efektif sehingga membutuhkan waktu dan tenaga yang maksimal.

2) Masalah mutu produk yang belum terjaga konsistensinya, belum adanya kendali kualitas produk yang bisa menjamin produk untuk siap bersaing. Pempek yang dijual ke konsumen seringkali tidak mempunyai rasa dan tekstur yang terjaga, sehingga berdampak komplain konsumen.

3) Belum dilakukan pembukuan yang tertib, kas keluar dan masuk tidak tercatat dengan baik, neraca bulanan belum dibuat, dan keuangan usaha dengan keuangan untuk konsumsi keluarga belum dipisah secara jelas. Hal inilah yang menyebabkan pengembangan usaha masih belum optimal.

\section{METODE PELAKSANAAN}

Untuk mencari cara penyelesaian masalah yang dihadapi oleh mitra, metode pendekatan dilakukan sesuai dengan permasalahan yang ada, baik yang menyangkut produksi dan manajemen.

\section{Alih teknologi mekanisasi pada produksi pempek}

Permasalahan yang dihadapi kedua mitra untuk memproduksi pempek yaitu proses pengulenan semua bahan yang dikerjakan secara manual selama 2-3 jam dengan cara manual maka dengan bantuan alat pengaduk adonan yang dikerjakan dengan dinamo listrik sehingga dapat mereduksi waktu yaitu dari 2-3 jam bisa 30-45 menit. Pengadonan secara konvensional menggunakan tangan setiap prose hanya mampu $3 \mathrm{~kg}$, maka dengan pengaduk mekanis dapat memproses $10 \mathrm{~kg}$ sekali proses.

\section{Pendampingan Penerapan Standar Sanitasi dan Hygiene Pada Produksi Pempek .}

Sanitasi dan hygiene merupakan faktor yang sangat penting untuk menghasilkan produk pangan yang aman. Oleh karena itu, sanitasi dan hygiene merupakan salah satu persyaratan dalam CPPB, karena bila terlihat dari hasil surve bahwa mitra belum sepenuhnya menerapkan standar hygiene pekerja, begitu 
juga untuk sanitasi lingkungan perlu dikontrol dengan baik. Jadi untuk mendapatkan produk pempek yang aman dikunsumsi, kedua mitra juga perlu diberi pencerahan tentang pentingnya standar sanitasi dan hygiene, Oleh karenanya pemberian kepada mitra tersebut juga perlu pengurusan Terdaftarnya merk dagang/sertifikat PIRT UKM IRT pempek dari Dinas Kesehatan Kota Malang dalam membentuk kelembagan. Hal ini sangat perlu pendampingan penerapannya perlu dilakukan melalui program IbM.

\section{Pelatihan manajemen, manajemen keuangan produksi dan manajemen pemasaran.}

Untuk peningkatan sumberdaya manusia /SDM dengan memberikan pelatihan dan pendampingan untuk memberikan wawasan dan ketrampilan pada pengelola usaha mikro pempek dalam proses produksi, manajemen dan pemasaran, sehingga pelaku usaha mikro pempek dapat mengelola usahanya dengan baik, bertanggungjawab dan menguntungkan. Hal ini diharapkan berdampak positif kepada pengelola usaha mikro pempek yang semakin meningkat kualitas manjemen dan pemasarannya sehingga omzet penjualan pempek meningkat jumlahnya dan meningkat keuntungannya.

\section{CAPAIAN}

\section{Aspek Produksi}

1. Frezzer untuk penyimpanan hasil pempek, bahan filled ikan dan cuko

Alat yang disumbangkan untuk mitra 1 (Pempek Maliana) adalah Freezer (alat pendingin. Hal ini sesuai dengan hasil diskusi mengenai kebutuhan mendesak yang dihadapi oleh pihak mitra I, yaitu alat pendingin. Alat pendingin (freezer dimaksudkan untuk :

a. Mengawetkan ikan segar untuk menunggu proses pembuatan pempek.

b. Mengawetkan pempek yang belum laku dan untuk penyimpanan stok pempek.

c. Memantapkan kuah pempek menjadi lebih kental dengan perlakuan pendinginan.

Setelah pemakaian frezzer sebagai alat pengawet maka pempek Maliana dapat meningkatkan produksi pempek kemudian disimpan di frezzer sambil menunggu order lewat media online seperti Facebook, Tweeter, Instagram dan $O L X$. Selain pempek yang dapat disimpan pada frezzer adalah filled ikan dan cuko.

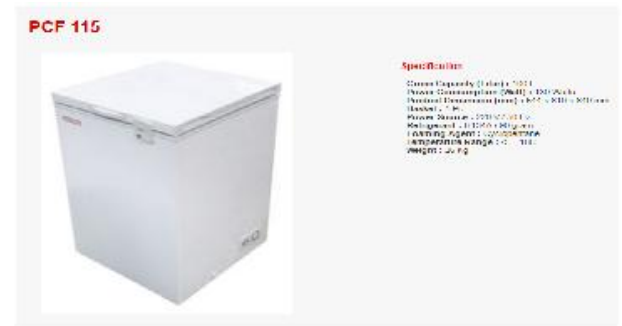

Gambar 1. Frezzeer polytron PCF 115

Peningkatan produksi terjadi, dari $5 \mathrm{~kg}$ pempek per dua hari sekarang mampu menghasilkan 5 $\mathrm{kg}$ hari. Sehingga terjadi peningkatan prduksi $100 \%$. Pemasaran semakin meluas dengan semain gencarnya promosi baik secara online maupun lewat demo dan tes produk kepada masyarakat.

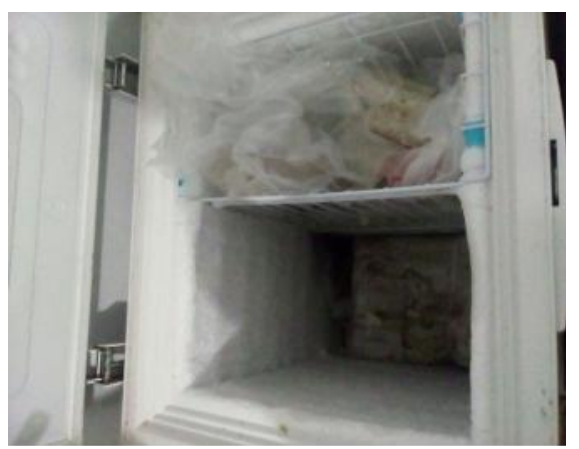

Gambar 2. Foto frezzer yang diisi bahan filled ikan

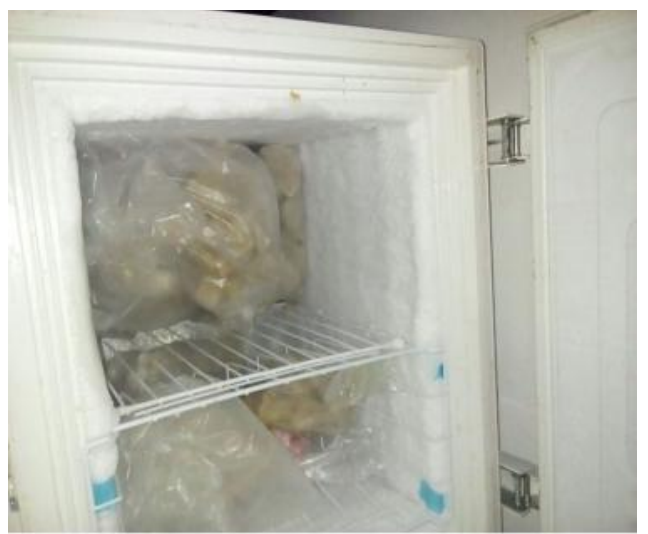

Gambar 3. Foto frezzer yang diisi pempek dan bahan filled ikan

\section{Mesin pengaduk adonan pempek}

Alat yang disumbangkan untuk mitra 2 (Pempek Sulfat 28) adalah Alat pengaduk adonan pempek dengan tenaga listrik. Hal ini sesuai dengan hasil diskusi mengenai kebutuhan mendesak yang dihadapi oleh pihak Mitra II, 
yaitu alat pengaduk adonan pempek. Alat pengaduk adonan pempek dimaksudkan untuk :

a. Menggantikan tenaga manual (manusia), sehingga lebih terjaga kualitas adonan pempek yang dibuat dan meningatkan kuantitas produksi.

b. Memproses adonan dengan waktu proses yang lebih singkat (30 menit), dibandingkan menggunakan tenaga manusia yang bisa mencapai waktu 1 jam.

c. Memproses adonan dengan jumlah bobot adonan lebih banyak, jika menggunkan tenaga manusia maka untuk $3 \mathrm{~kg}$ adonan diperlukan waktu 1 jam, sedangkan dengan menggunakan mesin pengaduk maka dapat diproduksi $9 \mathrm{~kg}$ setiap kali proses.

Hasil uji mesin pengaduk adonan pempek menunjukkan terjadi peningkatan jumlah produksi sebesar $9 \mathrm{~kg} / 3 \mathrm{~kg}=300 \%$, sedangkan efisiensi waktu sebesar 30 menit / 60 jam $=1 / 2, \quad$ sehingga waktu proses adonan menjadi lebih cepat 2 kali. Maka pada waktu proses yang meningkat kecepatannya 2 kali mampu menghasilkan produksi yang meningkat $300 \%$.

Peningkatan hasil uji mesin pengaduk adonan pempek baru mampu menyadarkan dan meyakinkan Ibu Ari Wahyuningtyas (Pempek Sulfat 28) beserta suaminya untuk akan memanfaatkan mesib pengaduk tersebut pada produksi pempeknya, hal ini mendukung perencanaan pembukaan cabang di Pasuruan pada waktu dekatl. Pada sisi lain mampu meningkatkan pasokan pempek untuk pedagang pengecer yang dilayaninya.

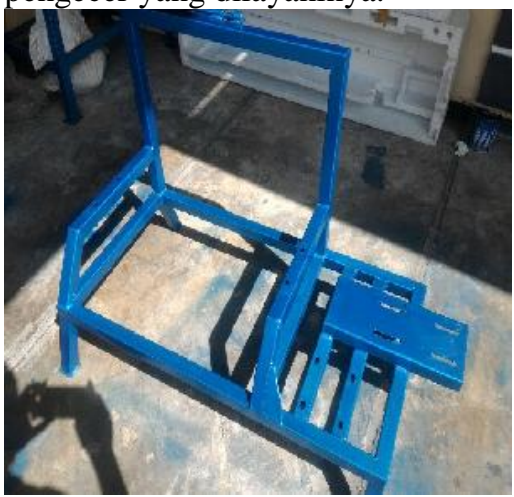

Gambar 4. Dudukan Mesin pengaduk adonan pempek

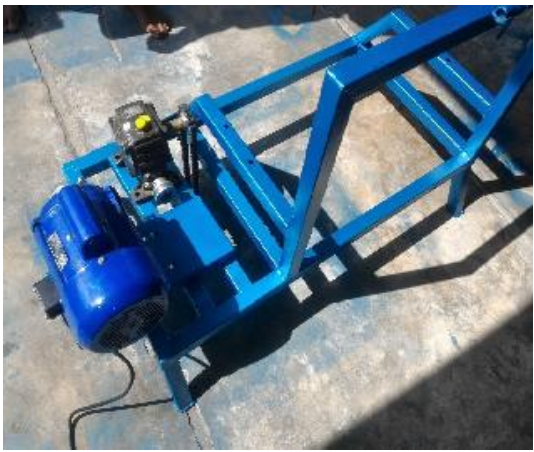

Gambar 5 Pemasangan motor penggerak dan reducer speed

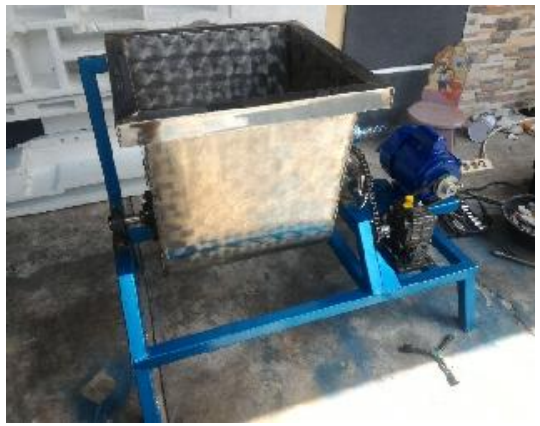

Gambar 6. Mesin pengaduk adonan pempek

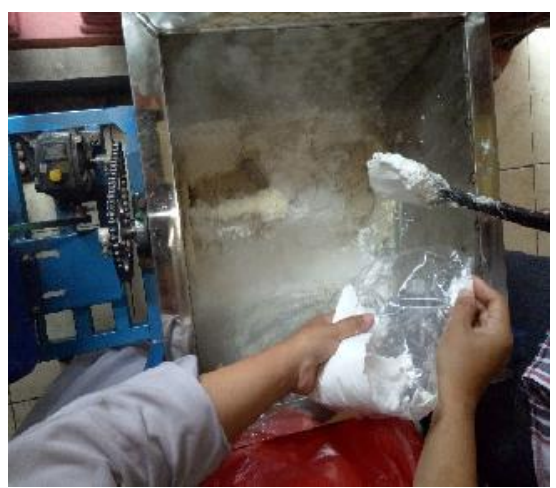

Gambar 7. Foto uji penggunakan mesin pengaduk adonan pempek

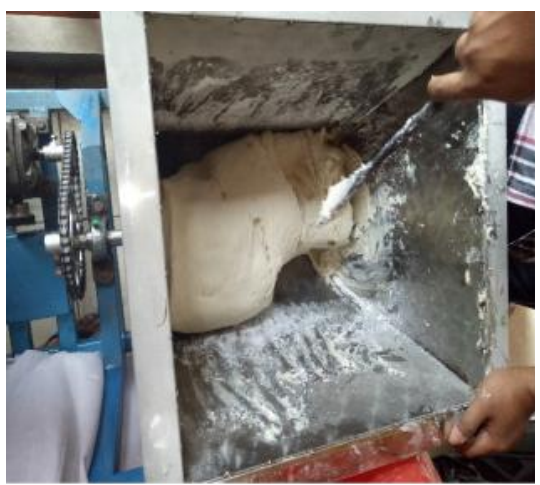

Gambar 8. Foto adonan pempek yang sudah kalis 


\section{Alat Vacum Sealer}

Alat vacum sealer diterimakan pada Mitra 1 yaitu pempek Maliana untuk mendukung daya simpan selama pengiriman pempek ke konsumen yang ada di luar kota Malang. Teknologi vacum selaer mampu memperpanjang daya simpan tradisional menjadi lebih lama yaitu satu minggu. Sehingga jangkauan kirim pempek Maliana bisa lebih luas.

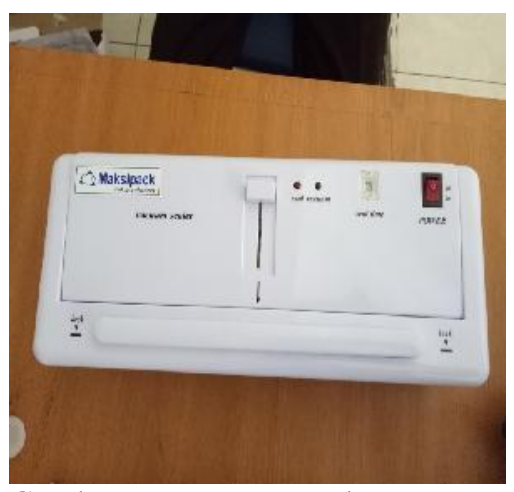

Gambar 9. Vacuum sealer

\section{Aspek Manajemen}

\section{Pelatihan dan Pendampingan Manajemen dan Keuangan Usaha}

Peningkatan kemampuan SDM pengusaha mikro dalam bidang manajemen usaha dan pembuatan laporan keuangan usaha secara sederhana dilakukan untuk memperkuat daya saing usaha. Kemampuan manajemen usaha yang baik diharapkan mampu meningkatkan pengelolaan usaha pempek yang mandiri dan berdaya saing. Kesadaran dan pemahaman proses produksi pempek yang sehat kemudian diinformasikan kepada masyarakat akan mampu mendorong peningkatan penjualan pempek.

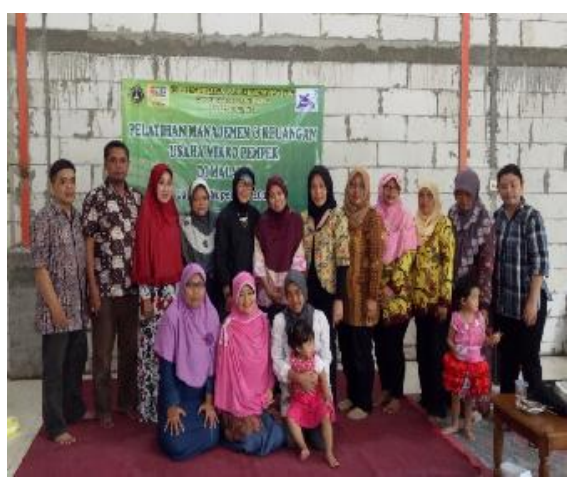

Gambar 10. Foto pelatihan manajemen usaha

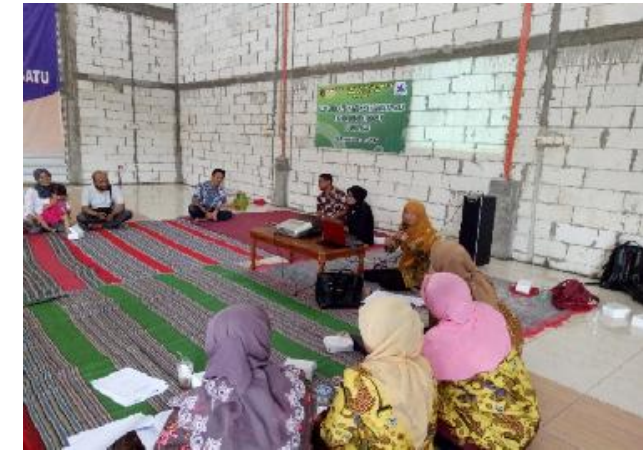

Gambar 11. Foto pelatihan pelaporan keuangan usaha sederhana

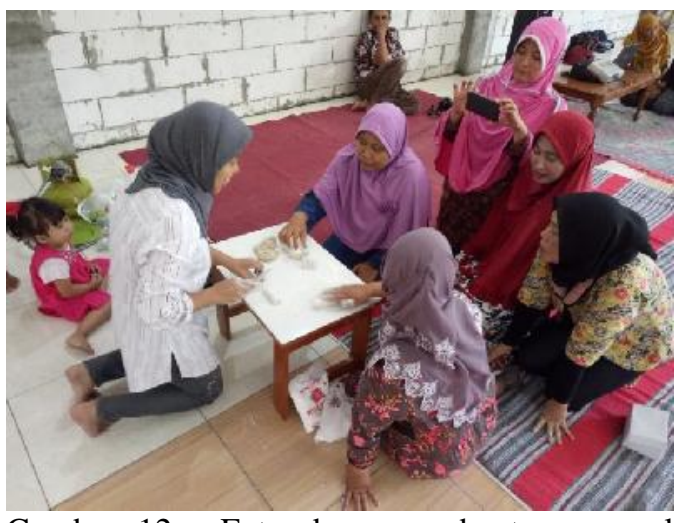

Gambar 12. Foto demo pembuatan pempek

yang inovatif dan sehat

\section{Potensi dan Peluang Bisnis}

Potensi dan peluang bisnis pempek ini sangat prospektif. Konsumen pempek di kota Malang menyebar dari tengah kota sampai dengan pinggiran kota, peminatnya dari tua sampai dengan anak-anak, dari kalangan ekonomi lemah sampai dengan orang kaya. Hal ini karena terkait dengan cita rasa pempek sebagai kudapan atau makanan yang disukai oleh konsumen. Sementara itu, kebutuhan akan pempek yang sehat dan kaya gizi karena mengandung sayuran tropis belum disentuh oleh pedagang pempek, sehingga sentuhan inovasi dan kreatifitas ini dapat menarik konsumen.

Fakta menunjukkan bahwa saat ini tersebar lapak-lapak penjual pempek dari tengah kota sampai dengan pinggiran, dari harga yang mahal sampai dengan harga yang terjangkau. Hal ini menunjukkan potensi untuk pemasaran pempek masih besar dan bisa dikembangan sebagai usaha yang mempunyai peluang yang cukup bagus.

\section{Implementasi Strategi dan Solusi}


Pengembangan produksi pempek di kota Malang memerlukan adanya solusi yang strategis sebagai langkah optimaslisasi kompetisi antar produk pempek. Strategi untuk meningkatkan produk pempek di kota Malang adalah dengan meningkatkan proses produksi yang sehat, cita rasa yang alami dan kandungan gizi dan nutrisi yang sehat. Hasil yang sudah dicapai dalam rangka strategi solusi atas permasalahan, berupa inovasi pengaduk adonan pempek dengan mekanisasi, penyimpanan bahan dengan frezzer dan peningkatan daya simpan pada pengiriman dengan vacuum sealer. Penggunaan mesin pengaduk adonan pempek mampu mempercepat proses produksi pempek secara efektif dan efisien.

Untuk masalah manajemen, strategi yang dilakukan antara lain dengan membuat informasi produk pempek yang mudah diakses oleh konsumen lewat internet dan media sosial. Pengelolaan keuangan dan pembukuan, dilaksanakan dengan sederhana sebagai upaya pencatatan kegiatan produksi, penjualan dan perhitungan keuntungan, sehingga dapat diketahui keuntungan sebagai pendapatan setiap periode tertentu, mingguan atau bulanan. Hal ini sebagai dasar untuk perencanaan usaha selanjutnya, apakah ditingkatkan produksinya atau perlu dilakukan diversifikasi jenis pempek untuk meingkatkan penjualan.

\section{KESIMPULAN DAN SARAN}

\section{Kesimpulan}

1. Pempek ikan dan nabati sayuran menjadi diversifikasi cita rasa pempek yang disukai anak-anak sampai dengan orang dewasa, sehingga meningkatkan daya jual pempek.

2. Frezzer sebagai wadah penyimpanan pempek dan bahan filled ikan mampu mendukung peningkatan produktifitas pempek.

3. Vacuum sealer mampu mendukung luas jangkauan pasar dengan meningkatkan daya simpan pempek selama pengiriman.

4. Mesin pengaduk adonan pempek mampu meningkatkan efisiensi dan jumlah produksi pempek.

5. Pelatihan manajemen dan keuangan usaha memberikan pemahaman pentingnya pengelolaan usaha rumah tangga dan pembukuan keuangan usaha.

6. Promosi produk pempek masih diperlukan untuk mengenalkan produk pempek yang inovasi, bergizi dan sehat.

\section{Saran}

IRT pempek di kota Malang perlu menjamin proses produksinya sehat dan menggunakan bahan yang aman dan sehat, selain meningkatkan diversifikasi cita rasa pempek yang lebih kreatif.

\section{DAFTAR PUSTAKA}

1. Anonymous, 2010. Potensi desa Mergosono kecamatan Kedungkandang Malang .id.wikipedia.org/wiki/Mergosono,_Kedun gkandang,_Malang

2. Anonymous, 2010. Cara buat adonan pempek palembang. tiraikasih.tripod.com/Cara_Membuat_Ad onan_Pempek.htm

3. Sandi Prastanto, 2010. Pempek Sudah Jadi Komoditas Ekspor. Antara. Palembang.

4. Suryana,Y dan Kartib Bayu, 2010. Kewirausahaan, Pendekatan Karakteristik Wirausahawan Sukses. Jakarta 